e-ISSN: 2550-1313 | p-ISSN: 2087-9849

http://jurnal.fkip.unila.ac.id/index.php/jpp/

\title{
Market Needs Assessment for Bachelor of Science in Industrial Security Management in a State-Funded College
}

\author{
Mark Erana Patalinghug*, Haidee F. Patalinghug \\ J.H. Cerilles State College- Dumingag Campus, Philippines \\ *Corresponding email: mark.patalinghug@jhcsc.edu.ph
}

Received: 16 November $2021 \quad$ Accepted: 20 December $2021 \quad$ Published: 30 December 2021

Abstract: Market Needs Assessment for Bachelor of Science in Industrial Security Management in a State-Funded College. Objective: This study was carried out to evaluate and appraise the market demand for a Bachelor of Science in Industrial Security in J.H. Cerilles State College, Philippines in 2021. Methods: The methodology used for this study was a descriptive survey conducted online using google forms. A random sampling method was used in selecting the 100 respondents from among students, graduates, and professionals from private and public institutions. Frequency counts, percentage, and weighted average mean were used in analyzing the data. Findings: The result revealed that offering BSISM in JHCSC is feasible as to the management viability, market viability, operation viability, and location, as well as industry viability. Conclusion: Competent and qualified teachers and staff are required for the long-term viability of the new program offering, with the availability of teaching resources being a secondary consideration in the decision to offer such a program. Location and future demand must also be given attention prior to proposing a new course.

Keywords: industrial security, security profession, market demand viability.

Abstrak: Penilaian Kebutuhan Pasar untuk Bachelor of Science in Industrial Security Management di Perguruan Tinggi Negeri. Tujuan: Studi ini dilakukan untuk mengevaluasi dan menilai permintaan pasar untuk gelar Bachelor of Science in Industrial Security di J.H. Cerilles State College, Filipina pada tahun 2021. Metode: Metodologi yang digunakan dalam penelitian ini adalah survei deskriptif yang dilakukan secara online menggunakan google form. Metode random sampling digunakan dalam memilih 100 responden dari kalangan mahasiswa, lulusan, dan profesional dari lembaga swasta dan publik. Frekuensi Hitung, Persentase, dan Rata-rata Tertimbang digunakan dalam menganalisis data. Temuan: Hasil penelitian menunjukkan bahwa penawaran BSISM di JHCSC layak untuk kelayakan manajemen, kelayakan pasar, kelayakan operasi, dan lokasi, serta kelayakan industri. Kesimpulan: Guru dan staf yang kompeten dan berkualitas diperlukan untuk kelangsungan jangka panjang dari penawaran program baru, dengan ketersediaan sumber daya pengajaran menjadi pertimbangan sekunder dalam keputusan untuk menawarkan program semacam itu. Lokasi dan permintaan di masa depan juga harus diperhatikan sebelum mengusulkan kursus baru.

Kata kunci: keamanan industri, profesi keamanan, kelayakan permintaan pasar.

\section{To cite this article:}

Patalinghug, M., E., \& Patalinghug, H., F. (2021). Market Needs Assessment for Bachelor of Science in Industrial Security Management in a State-Funded College. Jurnal Pendidikan Progresif, 11(3), 602-609. doi: 10.23960/jpp.v11.i3.202111. 


\section{INTRODUCTION}

Education is critical in determining the course of an individual's and a society's future. The existing and future economic, social, demographic, political, and technological elements that exist in the surroundings of the learners and education providers also have a significant impact on the quality of the education they get. Moreover, the course offered, its demand, and its need in the community are essential in determining the program's success for the years to come. As the demand and need change, the education system goes along with the trend. These modifications and adaptations are made in response to the shifting educational requirements of society.

Guidelines and policies produced following educational trends and prospects were developed on the government side to help shape the future of the educational system in one's country. The mission of Higher Education Institutions (HEIs) in the Philippines is to produce competent human resources both within the country and beyond. Given the industry's need for skilled workers and institutions' limited budgetary resources, streamlining program offerings has been a top management priority. This is why higher education is so essential for innovation and the development of human capital, and the survival and prosperity of the knowledgebased economy as a whole (van Vught, 2010).

Meanwhile, student expectations are evolving. Students' course selections were influenced by their perceptions of employment and scholarship prospects in a particular department (Okiror \& Denis, 2015). Learners are increasingly seeking courses that allow them to stay current on their expertise throughout their careers. Moreover, noteworthy to recognize that prior knowledge about a career is critical to fostering an interest in it. Preparation for a career results from past knowledge, enabling an individual to decide whether or not to pursue it (Nyamwange, 2016). Additionally, as learners want to acquire specific information or skills to meet labor market requirements, they increasingly choose to pick and choose courses from the most appropriate providers rather than enrolling in a traditional, clearly defined program at a single school (Tremblay et al., 2012). Hence, the desire to enhance academic curricula by adding new fields has recently increased in popularity(Solnet, 2012), and to achieve this, a needs assessment is performed to determine and validate the curriculum's genuine needs (McCawley, 2009).

One way to show that HEIs are adopting innovative ways to streamline the offered program in its offered curriculum is to open new programs that address the current demand for the educational economy. To do this, colleges or universities first conduct a market demand assessment for the targeted program offerings. First and foremost, market research must be conducted. The goal of colleges and universities is to provide programs that students are interested in, but these programs must also provide possibilities for students to be successful. This is a critical component of the program feasibility study since it links demand statistics to direct research feedback.

A feasibility study has become an essential tool for evaluating potential program offerings in higher education institutions. The Commission on Higher Education demands a feasibility study for any program proposed to be offered in the country's colleges and universities (Forlales, 2018).

The new Program Standard and Guidelines for BSISM under CMO 06 series of 2018, opens for new curricular offerings aligned with the criminal justice education(Commission on Higher Education 2018). Hence, opening the new curricular offering paves the way for students to enroll on BSISM instead of Bachelor of Science 
in Criminology, which is more stringent as it requires board examination. Moreover, the promulgation of the R.A. No. 11131, passing the Criminologist Licensure Examination (CLE), became a difficult hurdle to pass as regulations to promote quality in the profession were elevated (an act regulating the practice of the criminology profession in the Philippines) appropriating funds, therefore, repealing for the purpose republic act no. 6506 , otherwise known as "an act creating the board of examiners for criminologists in the philippine 2018).

To complement the higher standard of the BSCrim Program, the school aimed to maintain the quality and ensure that graduates would pass the CLE. In this scenario, school administration is looking to implement a high standard of retention policies among criminology students, however, facing difficulty as students have no other options on course to take or shift after failing the set standard of the BSCrim program. To still attain the vision and mission of J.H. Cerilles State College, offering a new program that would address the demand of the community and industry is the best option to implement.

Furthermore, it is expected that students will surge in numbers, enrolling in courses that the track of employment is aligned with the criminal justice system as there are many possibilities to be employed compared to other professions. Also, the increase in salary and allowances of the uniformed government personnel in 2019 increases students' interest in choosing law enforcement.

Meanwhile, the need to provide educational programs that satisfy the needs of today and the anticipated expectations of tomorrow cannot be overstated; nevertheless, it is even more critical to guarantee that the programs are of high quality. The industrialized world understands the value of certified programs and internationally recognized certifications. The educational programs that are offered are recognized, and the institutes must make every effort to have these programs accredited, as this takes time and effort. Furthermore, all educational institutions, including schools, colleges, and universities, must constantly improve the degree programs they already offer, whether they are accredited. It is also critical that the overall delivery of education be enhanced in all facets of its operation (Balingbing, 2014).

This study seeks to be a catalyst for producing competent academic programs of high quality that are systematically established and reviewed to ensure that they continue to satisfy the needs of the Criminal Justice and Security industry, which is rapidly increasing and evolving. Therefore, the researchers believed that this feasibility study would serve as the basis for the college administration to design a curricular program that addresses the trends and demands of today's employment and industry.

\section{METHODS}

In this study, the population size is around 150 individuals. Using Cochran's (1977) formula to compute the sample size, $50 \%$ of the population proportion were targeted to participate in this survey at a 0.05 margin of error with a confidence level of $95 \%$. This signifies that 109 or more measurements/surveys are required to achieve a 95\% confidence level that the actual value is within $5 \%$ of the measured/surveyed value. However, due to Covid-19 restrictions and the difficulty of gathering data from online participants, only 100 people have responded. The samples were taken from students, recent graduates, and working professionals from the industry, private sector, and government agencies that make up the study's sample. Respondents were randomly selected and voluntarily participated in the survey using Google forms. The data gathering was done in the month of April and May 2021. The procedures employed in this study were adopted 
from recent research, including location viability and industry demand viability (Forlales, 2018; Maaliw et al., 2021; Roble \& Tan, 2021).

Regarding ethical research, validation of two field experts and reliability testing of the questions were done and were determined fit for use. The online survey was designed with an opening page that outlines the purpose of the inquiry, the identity, and affiliation of the researchers, and specifies what participation would entail before requesting people to answer the questions (Alessi \& Martin, 2010). Additionally, respondents are told of the survey's aim and are assured that their data will be used solely for research purposes and that their name will be kept anonymous under Republic Act 10173, generally known as the Data Privacy Act of 2012, and on the Philippines Health Research Ethics Board (PHREB) guidelines on human research. The acquired data are analyzed using descriptive statistics such as frequency count, percentage, and weighted mean.

\section{RESULT AND DISCUSSIONS}

In the following tables and figures, the findings of this feasibility study are discussed in detailed manner.

Table 1. Profile of the respondents

\begin{tabular}{|l|lcc|}
\hline \multicolumn{2}{|c|}{ Profile } & F (f) & P (\%) \\
\hline \multirow{4}{*}{ Sex } & Male & 64 & 64.00 \\
\cline { 2 - 4 } & Female & 36 & 36.00 \\
\hline \multirow{5}{*}{ Age } & $\begin{array}{l}\text { 40-49 years } \\
\text { old }\end{array}$ & 22 & 22.00 \\
\cline { 2 - 4 } & $\begin{array}{l}30-39 \text { years } \\
\text { old }\end{array}$ & 30 & 30.00 \\
\cline { 2 - 4 } & $\begin{array}{l}\text { 20-29 years } \\
\text { old }\end{array}$ & 31 & 31.00 \\
\cline { 2 - 4 } & $\begin{array}{l}\text { Below 20 } \\
\text { years old and } \\
\text { below }\end{array}$ & 13 & 13.00 \\
\hline Civil Status & Single & 43 & 43.00 \\
\cline { 2 - 4 } & Married & 67 & 67.00 \\
\hline \multirow{2}{*}{$\begin{array}{l}\text { Educational } \\
\text { Qualification }\end{array}$} & College Level & 22 & 22.00 \\
\cline { 2 - 4 } & $\begin{array}{l}\text { Baccalaureate } \\
\text { Degree }\end{array}$ & 73 & 73.00 \\
\cline { 2 - 4 } & & & \\
\cline { 2 - 4 } & & & \\
\hline
\end{tabular}

\begin{tabular}{|l|lcc}
\cline { 2 - 3 } & $\begin{array}{l}\text { Master's } \\
\text { degree }\end{array}$ & 3 & 3.00 \\
\cline { 2 - 4 } & $\begin{array}{l}\text { Doctorate } \\
\text { Degree }\end{array}$ & 2 & 2.00 \\
\hline Agency & $\begin{array}{l}\text { Government } \\
\text { Service }\end{array}$ & 36 & 36.00 \\
\cline { 2 - 4 } & Private Sector & 42 & 42.00 \\
\cline { 2 - 4 } & Not Working & 22 & 22.00 \\
\hline $\begin{array}{l}\text { Current } \\
\text { Position/Rank }\end{array}$ & $\begin{array}{l}\text { Instructor/Prof } \\
\text { essor }\end{array}$ & 3 & 3.00 \\
\cline { 2 - 4 } & Police Officer & 18 & 18.00 \\
\cline { 2 - 4 } & Jail Officer & 21 & 21.00 \\
\cline { 2 - 4 } & $\begin{array}{l}\text { Security } \\
\text { Officer }\end{array}$ & 36 & 36.00 \\
\cline { 2 - 4 } & None & 22 & 22.00 \\
\hline
\end{tabular}

The respondents' profile is shown in Table 1. As indicated in the table, most respondents were male, many were between the ages of 20 and 29, and the majority were married. When it came to educational qualifications, the vast majority of respondents had earned their baccalaureate degree; many of these respondents were engaged in the private sector, where they worked as security officers and correctional officers, among other positions.

Table 2. Assessment of offering bachelor of science in industrial security management in terms of management, market, operational, location and demand viability

\begin{tabular}{lcc}
\hline \multicolumn{1}{c}{ Indicators } & WAM & I \\
\hline Management Viability & & \\
\hline $\begin{array}{l}\text { There are qualified faculty } \\
\text { to handle subjects in the }\end{array}$ & 3.58 & $\begin{array}{c}\text { Strongly } \\
\text { Agree }\end{array}$ \\
$\begin{array}{l}\text { Bachelor of Science in } \\
\text { Industrial Security? }\end{array}$ & & \\
\hline $\begin{array}{l}\text { The administration and } \\
\text { management of the J.H. }\end{array}$ & 3.52 & $\begin{array}{c}\text { Strongly } \\
\text { Agree }\end{array}$ \\
$\begin{array}{l}\text { Cerilles State College that } \\
\text { will handle the program are } \\
\text { highly competent. }\end{array}$ & & \\
\hline Market Viability & & \\
\hline $\begin{array}{l}\text { Senior Highschool } \\
\text { Graduate are interested in } \\
\text { enrolling Bachelor of }\end{array}$ & & Strongly \\
\end{tabular}


Science in Industrial

Security Management.

\begin{tabular}{|c|c|c|}
\hline Operational Viability & & \\
\hline $\begin{array}{l}\text { There are instructional } \\
\text { facilities available for the } \\
\text { Bachelor of Science in } \\
\text { Industrial Security } \\
\text { Management program. }\end{array}$ & 3.38 & $\begin{array}{c}\text { Strongly } \\
\text { Agree }\end{array}$ \\
\hline $\begin{array}{l}\text { There are adequate facilities } \\
\text { and equipment available in } \\
\text { the college to open the } \\
\text { Bachelor of Science in } \\
\text { Industrial Security } \\
\text { Management. }\end{array}$ & 3.62 & $\begin{array}{c}\text { Strongly } \\
\text { Agree }\end{array}$ \\
\hline Location Viability & & \\
\hline $\begin{array}{l}\text { The college is very } \\
\text { accessible for graduate } \\
\text { students. }\end{array}$ & 3.7 & $\begin{array}{l}\text { Strongly } \\
\text { Agree }\end{array}$ \\
\hline Industry Viability & & \\
\hline $\begin{array}{l}\text { There is a demand for } \\
\text { BSISM graduates in the } \\
\text { Academe, security industry } \\
\text { and other Law Enforcement } \\
\text { Agencies. }\end{array}$ & 3.7 & $\begin{array}{c}\text { Strongly } \\
\text { Agree }\end{array}$ \\
\hline $\begin{array}{l}\text { Graduates of the BSISM are } \\
\text { highly employable in both } \\
\text { private and public } \\
\text { institutions. }\end{array}$ & 3.38 & $\begin{array}{c}\text { Strongly } \\
\text { Agree }\end{array}$ \\
\hline $\begin{array}{l}\text { The BSISM program is } \\
\text { highly in demand in the } \\
\text { next } 5 \text { years }\end{array}$ & 3.47 & $\begin{array}{c}\text { Strongly } \\
\text { Agree }\end{array}$ \\
\hline Total & 3.51 & $\begin{array}{c}\text { Strongly } \\
\text { Agree }\end{array}$ \\
\hline
\end{tabular}

The managerial viability of the BSISM program is represented in Table 2 . The vast majority of those who responded strongly agreed that faculty members are qualified to teach subjects in the BSISM degree program. Furthermore, they were unanimous in their belief that the administration and management of the J.H. Cerilles State College administration and management have demonstrated that they are capable of managing the program. This further demonstrates that management viability is attainable in the context of the sample population studied. In terms of the marketability of the BSISM program, the vast majority of respondents strongly agreed that graduates of senior high school are interested in following the BSISM program after graduation. Further evidence that the program is marketable can be found in this instance.

Likewise, respondents firmly agreed that the college has suitable instructional facilities for the BSISM and adequate facilities and equipment for the program, as evidenced by their responses. Doing so ensures that the institution has the resources it needs to operate correctly and successfully and meet the needs of prospective students.

Furthermore, the respondents strongly agreed that the college is quite accessible for students and a readily available mode of public transportation. As a result, the college's location is ideal for establishing the BSISM program because it is easily accessible. Furthermore, recent studies suggest that location influences student achievement, which is due to the accessibility of the school (Aransi, 2019; Murphy, 2019b, 2019a; Musbahu et al., 2021). In addition, Ming (2010) noted that the location of a college or university could be a significant factor in a prospective student's decision to apply and enroll. Thus, having a course offered in an accessible location is advantageous.

According to most respondents, graduates of BSISM are highly sought after by industry and are expected to remain so for at least five years. Graduates of the BSISM program are in great demand by both private and public sector employers. Thus, the BSISM program is in high demand, and it can be implemented within the next five years.

Moreover, it was also noted that in courses with high demand and employability, it is possible to climb the ladder of success. Research further suggests that going up the corporate ladder is another essential consideration when making a career choice(Nyamwange, 2016). As noted, students' decision to enroll in a particular course or program is influenced mainly by economic 
variables, such as stable income and highdemand occupations (Malubay et al., 2015).

\section{Bachelor of Science in Industrial Security Program Program Respondents Perception}

Respondents' thoughts on a BSISM program at J.H. Cerilles State College are summarized in the following paragraphs.

"Its is beneficial for the school since the program is not a board coarse and yet graduates will land the same jobs with the graduate of Bachelor of Criminology graduates."

"It will become in demand as courses leading to law enforcement job is marketable due to the increase salary of uniformed men".

" The school will benefit from the program as those who are not qualified to Bachelor of Science in Criminology will be accepted by the program".

"This would increase the number of enrollees for Dumingag Campus"

"Security graduates have higher salaries compared to some profession yet expense during the study period is less."

" JHCSC is capable to open this program because of its faculty line-up and newly purchased laboratory facilities and equipment."

\section{CONCLUSIONS}

The present study is well compelling, providing solid evidence that delivering BSISM at the college level is a viable alternative. From the perspectives of management viability, market viability, operation viability, location, and industry viability, the findings of this feasibility study indicate that the school can establish a new program.

The curriculum at JH Cerilles State College will adapt to the changing demands of the community and business because of the result of this research engagement. Improvements in education services, curricular offerings, research, and extension should be made continuingly to meet the future demand for this field. It is possible to duplicate the methods used in this study in a future feasibility evaluation, including other aspects that were not included in this study.

\section{- ACKNOWLEDGMENT}

Particular acknowledgment is due to Dr. Mary Jocelyn V. Battung, the college president, for giving assistance with the project (BSISM Feasibility Study). We would also want to express our gratitude to everyone who took the time to complete the online survey form; without your participation, this study would not have been successful.

\section{REFERENCES}

Alessi, E. J., \& Martin, J. I. (2010). Conducting an internet-based Survey: Benefits, pitfalls, and lessons learned. Social Work Research, 34(2), 122-128.

Aransi, O. W. (2019). Teachers 'Variable and School Location As Predictors Of Students 'Academic Performance In Economics In Osun State, Nigeria. International Journal of Academic and Applied Research, 3(4), 19-26.

Balingbing, A. (2014). A Feasibility Study on Offering Bachelor of Arts in Information Technology (With Business Track on Business Processing Outsourcing). Asia Pacific Journal of Education, Arts and Sciences, 1(1), 64-69.

Cochran, W. G. (1977). Sampling Techniques. 3rd ed. New York: John Wiley \& Sons. (3rd ed.). John Wiley \& Sons.

Commission on Higher Education. (2018). CMO No. 06, Series 2018-Policies, Standars and Gudidelines For The Bachelor. of Science in Industrial Security Management (BSISM). Program.

Forlales, E. L. (2018). Feasibility study on 
offering Master of Engineering in Romblon State University, Philippines. International Journal of Scientific Engineering and Research, 6(7), 118116. www.ijser.in

Maaliw, R. I., Salvatierra-bello, D., Placino-seño, M., \& Danganan, R. V. (2021). A Feasibility Study on the Program Offering of Bachelor of Science in Information Technology (Web and Mobile Applications Development).

Malubay, G. J. J., Mercado, K. A. O., \& Macasaet, E. (2015). Factors Affecting the Decision of Freshmen Students in Pursuing Hospitality and Tourism Programs in Lyceum of the Philippines UniversityLaguna: Basis for Enhancement. LPULaguna Journal of International Tourism and Hospitality Management, 3(1), 23-48.

McCawley, P. F. (2009). Methods for conducting an educational needs assessment. University of Idaho, 23(6-14).

Ming, J. S. K. (2010). Institutional Factors Influencing Students' College Choice Decision in Malaysia. International Journal of Business and Social Science, 1(3), 53-58.

Murphy, S. (2019a). Participation and achievement in technology education: the impact of school location and socioeconomic status on senior secondary technology studies. International Journal of Technology and Design Education, 30(2), 349-366.

Murphy, S. (2019b). School location and socioeconomic status and patterns of participation and achievement in senior secondary mathematics. Mathematics Education Research Journal, 31(3), 219-235.

Musbahu, A., Oluyemo, A. A., Jesse, V. S.,
Safo, A. D., \& Amos, I. (2021). Influence of School Location and Interest in Secondary School Students Academic Achievement in Mathematics Niger State Nigeria. International Journal of Research and Innovation in Social Science, V(III), 161-167.

Nyamwange, J. (2016). Influence of Student ' s Interest on Career Choice among First Year University Students in Public and Private Universities in Kisii County, Kenya. Journal of Education and Practice, 7(4), 96-102. www.iiste.org

Okiror, J. J., \& Denis, O. (2015). Factors influencing career choice among undergraduate Students in an African university context: The Case of Agriculture Students at Monitoring and evaluation of Crop Intensification Program activities in Rwanda View project Climate Change and Rural Insti. Journal of Dynamics in Agricultural Research, 2(2), 12-20.

Republic Act No. 11131 “An Act Regulating the Practice of Criminology Proffesion in the Phillipines, and Appropriating Funds Therefor, Repealing for the Purpose Republic Act NO. 6506, Otherwise Known as "An Act Creating the Board of Examiners for Criminologists in the Phillipine, Pub. L. No. R.A. 11131 (2018).

Roble, D. B., \& Tan, R. G. (2021). A feasibility study on the university of science and technology of the southern philippines offering a bachelor of elementary education major in science, technology, engineering, and mathematics (STEM). Asia Pacific Journal of Educational Perspectives, $8(1), 38-43$.

Solnet, D. (2012). Service Management in Hospitality Education: Review and Reflection. Journal of Hospitality 
Marketing and Management, 21(2), 184-214.

Tremblay, K., Lalancette, D., \& Roseveare, D. (2012). Assessment of Higher Education Learning Outcomes: Feasibility Study Report, Volume 1Design and Implementation. In Paris, France: Organisation for Economic Co-operation and Development. (Vol. $1)$.

van Vught, F. (2010). Mapping the Higher Education Landscape: Towards a European Classification of Higher Education. In Springer Science \& Business Media. (Vol. 28). Springer Science \& Business Media. 